\title{
Influence of Bismuth Oxide on Dielectric Properties of Barium Titanate Solid Solution
}

\author{
Received 5 July, 2021; revised 15 July, 2021; accepted 29 July, 2021
}

\author{
Yeon Jung Kim* \\ College of Engineering, Dankook University, Yongin 16890, Republic of Korea
}

*Corresponding author E-mail: yjkim80@dankook.ac.kr

\begin{abstract}
$\mathrm{A} \mathrm{Ba}_{0.9} \mathrm{Bi}_{0.1} \mathrm{TiO}_{3}$ solid solution was prepared by substituting 0.1 mole $\% \mathrm{Bi}_{2} \mathrm{O}_{3}$ at the $\mathrm{Ba}^{2+}$ sites in $\mathrm{BaTiO}_{3}$, and its dielectric properties were investigated. The $\mathrm{Ba}_{0.9} \mathrm{Bi}_{0.1} \mathrm{TiO}_{3}$ solid solution was sintered at $1310{ }^{\circ} \mathrm{C}$ for $5 \mathrm{~h}$. The stable formation of the perovskite structure was confirmed through X-ray diffraction, energy-dispersive $\mathrm{X}$-ray spectroscopy, and field emission scanning electron microscopy. Unlike pure $\mathrm{BaTiO}_{3}$, pyrochlore $\mathrm{Bi}_{2} \mathrm{Ti}_{2} \mathrm{O}_{7}$ was observed in $\mathrm{Ba}_{0.9} \mathrm{Bi}_{0.1} \mathrm{TiO}_{3}$ at approximately $27.1^{\circ}$. Overall, the perovskite structure was well formed. The $\mathrm{Ba}_{0.9} \mathrm{Bi}_{0.1} \mathrm{TiO}_{3}$ solid solution showed typical dielectric properties and followed the modified Curie-Weiss law. In addition, the curve of the dielectric constant vs. temperature showed an extremely gradual change compared to the phase transition behavior of $\mathrm{BaTiO}_{3}$.
\end{abstract}

Keywords: $\mathrm{Ba}_{0.9} \mathrm{Bi}_{0.1} \mathrm{TiO}_{3}$, Dielectric properties, Phase transition, Modified Curie-Weiss law

\section{Introduction}

The requirement for ecofriendly electric and electronic materials, particularly multilayer ceramic capacitors, is increasing in the fields of information technology and artificial intelligence. Ecofriendly $\mathrm{BaTiO}_{3}$ is suitable for meeting this requirement, and it has the potential to be actively used in these fields. As shown in Fig. $1, \mathrm{BaTiO}_{3}$ consists of $\mathrm{Ti}^{4+}$ at octahedral coordination sites and $\mathrm{Ba}^{2+}$ at 12-coordinated sites in a high-temperature Pm3m cubic symmetry. Spontaneous polarization occurs owing to noncentrosymmetric displacement in the ferroelectric state below $120^{\circ} \mathrm{C}$. As $\mathrm{BaTiO}_{3}$ is a relatively simple compound, it is easy to synthesize it using appropriate impurities or additives such as $\mathrm{La}^{3+}, \mathrm{Sb}^{3+}, \mathrm{Nb}^{5+}, \mathrm{Ta}^{5+}, \mathrm{Co}^{2+}$, and $\mathrm{Ni}^{2+}$. Thus, it is possible to fabricate an efficient dielectric with a high electric field strength and frequency-dependent properties. In this respect, $\mathrm{BaTiO}_{3}$ is an excellent electronic material with various advantages over other materials $[1-5]$.

In this study, $\mathrm{Ba}_{0.9} \mathrm{Bi}_{0.1} \mathrm{TiO}_{3}$ was synthesized by substituting $\mathrm{Bi}^{3+}$ in $\mathrm{BaTiO}_{3}$, and the effects of the substitution on perovskite structures and dielectric properties were analyzed. The substitution mechanism was examined because it strongly affects defect generation, crystal structure, and overall dielectric properties.

\section{Experimental details}

The $\mathrm{Ba}_{0.9} \mathrm{Bi}_{0.1} \mathrm{TiO}_{3}$ solid solution was prepared by synthesizing $\mathrm{BaO}$, $\mathrm{TiO}_{2}$, and $\mathrm{Bi}_{2} \mathrm{O}_{3}$ with a purity of $99.9 \%$ or higher. The mole fractions of $\mathrm{BaO}, \mathrm{TiO}_{2}$, and $\mathrm{Bi}_{2} \mathrm{O}_{3}$ were 13.7997, 7.9900, and 2.3298, respectively. Calcination was carried out in 10 intervals at $1150-1200^{\circ} \mathrm{C}$. The powder synthesized at $1180^{\circ} \mathrm{C}$ was stably calcined, and it had the highest perovskite content. Sintering was performed using this powder. The specimen used for characterization was a disk-shaped $\mathrm{Ba}_{0.9} \mathrm{Bi}_{0.1} \mathrm{TiO}_{3}$ solid solution, which was synthesized by sintering at $1310{ }^{\circ} \mathrm{C}$ for $5 \mathrm{~h}$. The ionic radius of $\mathrm{Bi}^{3+}(153 \mathrm{pm})$ is half of that of $\mathrm{Ba}^{2+}$

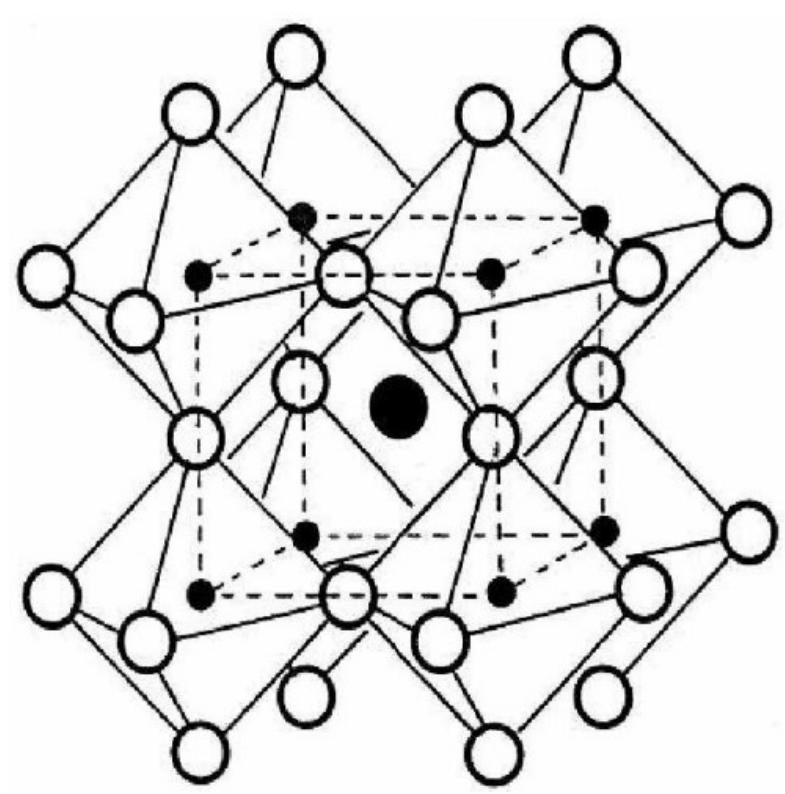

Figure 1. Perovskite $\mathrm{BaTiO}_{3}$ with the $\mathrm{Ba}^{2+}$ at the center of the cell and $\mathrm{Ti}^{4+}$ inside the oxygen octahedra.

(255 pm); hence, a charge imbalance of cations may occur. The formation and atomic ratio of the perovskite structure of the $\mathrm{Ba}_{0.9} \mathrm{Bi}_{0.1} \mathrm{TiO}_{3}$ solid solution were observed using X-ray diffraction (XRD), energydispersive X-ray spectroscopy (EDS), and field emission scanning electron microscopy (FESEM), which are general-purpose analytical methods. The capacitance and dielectric loss of the $\mathrm{Ba}_{0.9} \mathrm{Bi}_{0.1} \mathrm{TiO}_{3}$ solid solution were obtained using an LCR meter. They were measured as a function of temperature at frequencies of $10^{2}-10^{5} \mathrm{~Hz}$ and a heating rate of $4{ }^{\circ} \mathrm{C} / \mathrm{min}$. 


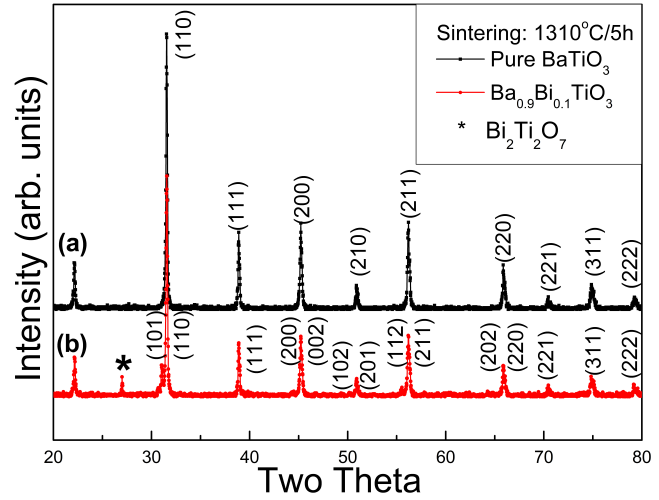

Figure 2. XRD patterns of (a) pure $\mathrm{BaTiO}_{3}$ and (b) $\mathrm{Ba}_{0.9} \mathrm{Bi}_{0.1} \mathrm{TiO}_{3}$ solid solutions.

\section{Results and discussion}

Crystallographically pure $\mathrm{BaTiO}_{3}$ crystals have two phases: tetragonal and cubic. Figure 2 shows the XRD results of $\mathrm{BaTiO}_{3}$ and $\mathrm{Ba}_{0.9} \mathrm{Bi}_{0.1} \mathrm{TiO}_{3}$. The (222) pyrochlore phase was not observed. However, (110) perovskite, which is an evidence of the perovskite structure, was clearly observed. Therefore, the specimens calcined at 1180 ${ }^{\circ} \mathrm{C}$ and sintered at $1310^{\circ} \mathrm{C}$ for $5 \mathrm{~h}$ formed a stable perovskite structure at the current level and satisfied the appropriate heat treatment conditions. However, in the specimen substituted with $\mathrm{Bi}_{2} \mathrm{O}_{3}$, the XRD intensity corresponding to pyrochlore $\mathrm{Bi}_{2} \mathrm{Ti}_{2} \mathrm{O}_{7}$ was observed at approximately $27.1^{\circ}$. Phases at approximately $35^{\circ}$ and $49^{\circ}$ could not be clearly identified. However, these phases were observed in previous studies. In particular, when more than 0.15 mole $\% \mathrm{Bi}^{3+}$ was substituted in $\mathrm{BaTiO}_{3}$, pyrochlore $\mathrm{Bi}_{2} \mathrm{Ti}_{2} \mathrm{O}_{7}$ was more clearly observed in $\mathrm{XRD}$ data. Therefore, a stable perovskite structure can be obtained if the substitution amount of $\mathrm{Bi}^{3+}$ is adjusted to approximately 0.1 mole $\%$. It was speculated that it was sintered to a high density at $1310{ }^{\circ} \mathrm{C}$ and $\mathrm{Ba}_{0.9} \mathrm{Bi}_{0.1} \mathrm{TiO}_{3}$ had a stable $\left(\mathrm{A}_{1} \mathrm{~A}_{2}\right) \mathrm{BO}_{3}$ complex perovskite structure. Consequently, the dielectric properties over a wide temperature range can be improved.

The substitution of the $\mathrm{A}$ and $\mathrm{B}$ sites of pure $\mathrm{BaTiO}_{3}$ with other ions strongly affects its physical properties, such as dielectric, piezoelectric, and pyroelectric properties. Figure 3 shows the EDS results of pure $\mathrm{BaTiO}_{3}$ and $\mathrm{Ba}_{0.9} \mathrm{Bi}_{0.1} \mathrm{TiO}_{3}$. The EDS spectrum of pure $\mathrm{BaTiO}_{3}$ was typical. The atomic percentages of $\mathrm{Ba}^{2+}, \mathrm{Ti}^{4+}$, and $\mathrm{O}^{2-}$ were 18.95 (58.14 wt \%), 18.09 (19.36 wt \%), and $62.96 \%$ (22.50 wt \%), respectively. However, the EDS spectrum of $\mathrm{Ba}_{0.9} \mathrm{Bi}_{0.1} \mathrm{TiO}_{3}$ clearly showed that the substitution of $\mathrm{Bi}^{3+}$ was related to inhomogeneous particles. In this case, the atomic percentages of $\mathrm{Ba}^{2+}, \mathrm{Ti}^{4+}$, and $\mathrm{O}^{2-}$ were 38.25 (69.71 wt \%), 25.35 (17.21 wt \%), and $33.12 \%$ (7.270 wt \%), respectively, and approximately $3.280 \%(5.810 \mathrm{wt} \%) \mathrm{Bi}^{3+}$ was observed. This was due to the nonuniform distribution of $\mathrm{Bi}^{3+}$ and the separation of the sample, resulting in a partial nonferroelectric region in the $\mathrm{BaTiO}_{3}$ specimen. However, there was no significant change in dielectric properties. There was a relatively large difference between the atomic compositions of pure $\mathrm{BaTiO}_{3}$ and $\mathrm{Ba}_{0.9} \mathrm{Bi}_{0.1} \mathrm{TiO}_{3}$. It has been reported that the addition or substitution of impurities strongly affects the crystallization kinetics of a solid solution. This effect can be interpreted as follows: Generally, the diffusion dynamics of the elements that constitute each oxide during the heat treatment process are significantly affected by the presence of charge compensation defects. As the atomic radius of $\mathrm{Bi}^{3+}(153 \mathrm{pm})$ is $60 \%$ of that of $\mathrm{Ba}^{2+}(255 \mathrm{pm})$, charge imbalance was observed during the experiment in this study owing to the difference in the oxidation state. In terms of the ionic radii of two ions at an $\mathrm{A}$ site, $\mathrm{Ba}^{2+}$ can be substi-

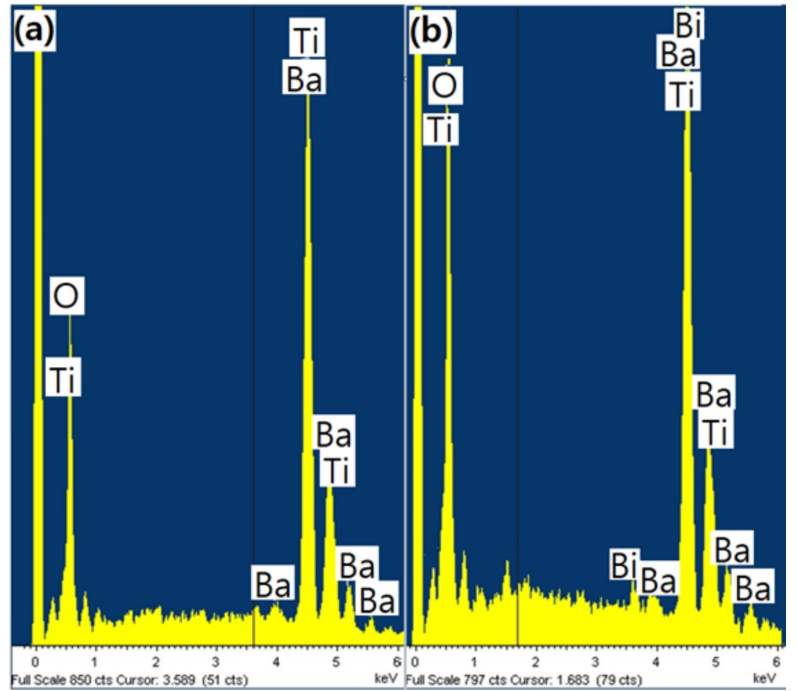

Figure 3. EDS spectra of (a) pure $\mathrm{BaTiO}_{3}$ and (b) $\mathrm{Ba}_{0.9} \mathrm{Bi}_{0.1} \mathrm{TiO}_{3}$ solid solutions.

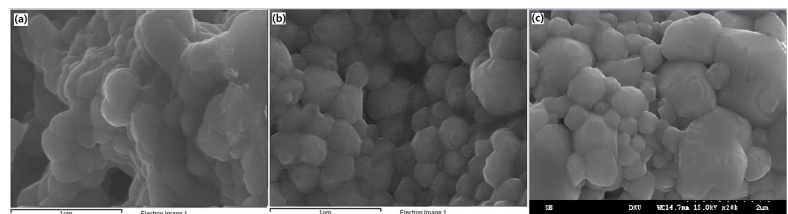

Figure 4. FESEM micrographs of (a) pure $\mathrm{BaTiO}_{3}$, (b) $\mathrm{Ba}_{0.9} \mathrm{Bi}_{0.1} \mathrm{TiO}_{3}$, and (c) $\mathrm{Ba}_{0.9} \mathrm{Sb}_{0.1} \mathrm{TiO}_{3}$ solid solutions.

tuted by $\mathrm{Bi}^{3+}$ in the perovskite lattice. Furthermore, low-valence ions are substituted by high-valence ions. Thus, $\mathrm{Ba}_{0.9} \mathrm{Bi}_{0.1} \mathrm{TiO}_{3}$ is synthesized as a defect in the charge and structure. The substitution of $\mathrm{Ba}^{2+}$ with $\mathrm{Bi}^{3+}$ causes a charge compensation reaction and changes the pore concentration of the crystal because of the difference in the atomic radii and valences. As stated earlier, approximately $3.280 \%(5.810$ wt \%) $\mathrm{Bi}^{3+}$ was detected in $\mathrm{Ba}_{0.9} \mathrm{Bi}_{01} \mathrm{TiO}_{3}$. At this atomic percentage, the effect of $\mathrm{Bi}^{3+}$ on microstructural uniformity is not a major problem. Figures 4(a)-(c) show the surface micrographs of $\mathrm{BaTiO}_{3}$, $\mathrm{Ba}_{0.9} \mathrm{Bi}_{0.1} \mathrm{TiO}_{3}$, and $\mathrm{Ba}_{0.9} \mathrm{Sb}_{0.1} \mathrm{TiO}_{3}$, respectively. In polycrystals, the number of pores and impurities decreases because of heat treatment at high temperatures, and crystal grains generally grow. As shown in Fig. 4(c), the particle size of the sintered $\mathrm{Ba}_{0.9} \mathrm{Sb}_{0.1} \mathrm{TiO}_{3}$ solid solution was approximately $2.0 \mu \mathrm{m}$, indicating a relatively dense particle arrangement. However, as shown in Fig. $4(\mathrm{~b})$, sintered $\mathrm{Ba}_{0.9} \mathrm{Bi}_{0.1} \mathrm{TiO}_{3}$ consisted of dense and relatively small grains. This implied that the particle size was slightly smaller than that of $\mathrm{BaTiO}_{3}$ systems with a donor dopant $[6,7]$. In complex structured perovskites, the energy required to stably bind displaced ions of different ionic radii and valences at each lattice site is associated with the formation of compensatory defects. On the basis of the XRD results shown in Fig. 2, it was judged that $\mathrm{Ba}_{0.9} \mathrm{Bi}_{0.1} \mathrm{TiO}_{3}$ sintered at $1310{ }^{\circ} \mathrm{C}$ had relatively normal grain growth and a uniform microstructure. The presence of chemically heterogeneous systems in $\mathrm{Ba}_{0.9} \mathrm{Bi}_{0.1} \mathrm{TiO}_{3}$ specimens was different from that in $\mathrm{Nb}^{5+}$-substituted and $\mathrm{Ta}^{3+}$-substituted $\mathrm{BaTiO}_{3}$ systems but quite similar to that in recently reported $\mathrm{Sb}^{3+}$-substituted $\mathrm{Ba}_{1-\mathrm{x}} \mathrm{Sb}_{\mathrm{x}} \mathrm{TiO}_{3}$ systems [3].

The dielectric constant and dielectric loss of $\mathrm{BaTiO}_{3}$, $\mathrm{Ba}_{0.9} \mathrm{Bi}_{0.1} \mathrm{TiO}_{3}$, and $\mathrm{Ba}_{0.9} \mathrm{Bi}_{0.1} \mathrm{TiO}_{3}$ were measured at frequencies of $10^{2}-10^{5} \mathrm{~Hz}$ to analyze the frequency dependence of these properties. The results are shown in Fig. 5. As the frequency increased, the dielectric constant decreased and the dielectric loss increased. At frequencies higher than $10^{3} \mathrm{~Hz}$, the dielectric constant of $\mathrm{Ba}_{0.9} \mathrm{Bi}_{0.1} \mathrm{TiO}_{3}$, which required more energy for the rotation of dipoles in polycrystals, 


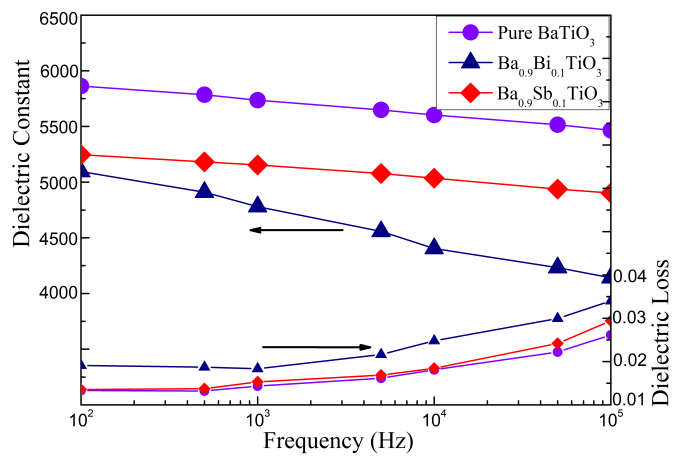

Figure 5. Frequency dependence of dielectric properties of $\mathrm{BaTiO}_{3}, \mathrm{Ba}_{0.9} \mathrm{Bi}_{0.1} \mathrm{TiO}_{3}$, and $\mathrm{Ba}_{0.9} \mathrm{Sb}_{0.1} \mathrm{TiO}_{3}$ solid solutions.

decreased more rapidly than that of $\mathrm{BaTiO}_{3}$ and $\mathrm{Ba}_{0.9} \mathrm{Sb}_{0.1} \mathrm{TiO}_{3}$. This was accompanied by a rapid increase in the dielectric loss. These dielectric properties of $\mathrm{Ba}_{0.9} \mathrm{Bi}_{0.1} \mathrm{TiO}_{3}$ were considered to be caused by the $\mathrm{Bi}_{2} \mathrm{Ti}_{2} \mathrm{O}_{7}$ pyrochlore phase generated in polycrystals by the substitution of $\mathrm{Ba}^{2+}$ with $\mathrm{Bi}^{3+}$. The absolute value of the dielectric constant decreased in the case of $\mathrm{Bi}^{3+}$ substitution compared to $\mathrm{Sb}^{3+}$; however, the frequency stability improved. This phenomenon in the $\mathrm{BaTiO}_{3}$ system has been reported by several other researchers [8-10]. In general, when trivalent ions, such as $\mathrm{Bi}^{3+}, \mathrm{La}^{3+}$, and $\mathrm{Sb}^{3+}$, are substituted in $\mathrm{BaTiO}_{3}$ systems, they occupy $\mathrm{Ba}^{2+}$ sites because of similar ionic radii and electronegativities. Therefore, $\mathrm{Bi}^{3+}$ located at the $\mathrm{A}$ site of perovskite $\mathrm{BaTiO}_{3}$, which is $\mathrm{Ba}^{2+}$ site, attempts to maintain charge balance. Hence, electron and/or barium vacancies occur, for example, $\mathrm{Bi}_{\mathrm{Ba}} \rightarrow \mathrm{Bi}^{*}{ }_{\mathrm{Ba}}+e^{\prime}$ and $\mathrm{Bi}_{\mathrm{Ba}} \rightarrow \mathrm{Bi}^{*}{ }_{\mathrm{Ba}}+(1 / 2) \mathrm{V}_{\mathrm{Ba}}^{\prime \prime}$. In this process, $\mathrm{Bi}^{*}{ }_{\mathrm{Ba}}$ is the ionized $\mathrm{Bi}^{2+}$ donor, $\mathrm{V}^{\prime \prime}{ }_{\mathrm{Ba}}$ is the double ionized barium vacancy, and $\mathrm{e}^{\prime}$ is the electron. In the case of substitution with a low $\mathrm{Bi}^{2+}$ concentration, as in this study, compensation occurs via $\mathrm{Bi}_{\mathrm{Ba}} \rightarrow \mathrm{Bi}^{*}{ }_{\mathrm{Ba}}+\mathrm{e}^{\prime}$. At high $\mathrm{Bi}^{3+}$ concentrations, compensation occurs via $\mathrm{Bi}_{\mathrm{Ba}} \rightarrow \mathrm{Bi}^{*}{ }_{\mathrm{Ba}}+(1 / 2) \mathrm{V}_{\mathrm{Ba}}^{\prime \prime}$, similar to other trivalents. This may imply that there are numerous crystal defects in the crystal structure of $\mathrm{Ba}_{0.9} \mathrm{Bi}_{0.1} \mathrm{TiO}_{3}$ and shows that $\mathrm{Bi}^{3+}$ partially substitutes $\mathrm{Ba}^{2+}$ at the A site of $\mathrm{ABO}_{3}$. Therefore, when $\mathrm{Bi}^{3+}$ substitution occurs in pure $\mathrm{BaTiO}_{3}$ under suitable conditions, the local disorder around $\mathrm{Ba}^{2+}$ atoms is reduced. Moreover, the local structure of $\mathrm{Ti}^{4+}$ is affected to a certain extent $[11,12]$.

Figure 6 shows the plot of $\ln \left[(1 / \mathrm{K})-\left(1 / \mathrm{K}_{\mathrm{m}}\right)\right]$ vs. $\ln \left(\mathrm{T}-\mathrm{T}_{\mathrm{m}}\right)$ for $\mathrm{Ba}_{0.9} \mathrm{Bi}_{0.1} \mathrm{TiO}_{3}$, where $\mathrm{K}$ is the dielectric constant, $\mathrm{K}_{\mathrm{m}}$ is the maximum dielectric constant, $\mathrm{T}$ is the temperature, $\mathrm{T}_{\mathrm{m}}$ is the dielectric constant maximum temperature. A dielectric reaction that continuously decreased the dielectric constant in the phase transition region was observed. This showed a certain degree of singularity, which was different from that of pure $\mathrm{BaTiO}_{3}$. In other words, unlike $\mathrm{BaTiO}_{3}, \mathrm{Ba}_{0.9} \mathrm{Bi}_{0.1} \mathrm{TiO}_{3}$ did not exhibit perfect diffusion ferroelectricity. The modified Curie-Weiss quadratic equation, $1 / \mathrm{K}=1 / \mathrm{K}_{\mathrm{m}}+[(\mathrm{T}-$

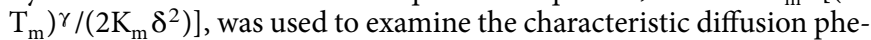
nomenon, where $\delta$ is the diffusion parameter and $\gamma$ is the critical in$\operatorname{dex}[9,10,13]$. The substitution of $\mathrm{Ba}^{2+}$ with $\mathrm{Bi}^{3+}$ made it possible to maintain the ferroelectric phase over a wide temperature range and changed the degree of $\delta$, thereby making $\gamma$ larger than 1 . The diffusivity of $\mathrm{Ba}_{0.9} \mathrm{Bi}_{0.1} \mathrm{TiO}_{3}$ could be expressed in terms of $\gamma$. In addition, $\gamma$ of $\mathrm{Ba}_{0.9} \mathrm{Bi}_{0.1} \mathrm{TiO}_{3}$ slightly decreased as the sintering temperature increased (data not shown in this report). It has been reported that this dielectric diffusion phenomenon is due to the change in the local composition caused by the formation of multiple microdomains within the crystal structure [8-10]. The inset in Fig. 6 shows the change in the reciprocal dielectric constant of the $\mathrm{Ba}_{0.9} \mathrm{Bi}_{0.1} \mathrm{TiO}_{3}$ solid solution as a function of temperature. Substitution with $\mathrm{Bi}^{3+}$ at a low concentra-

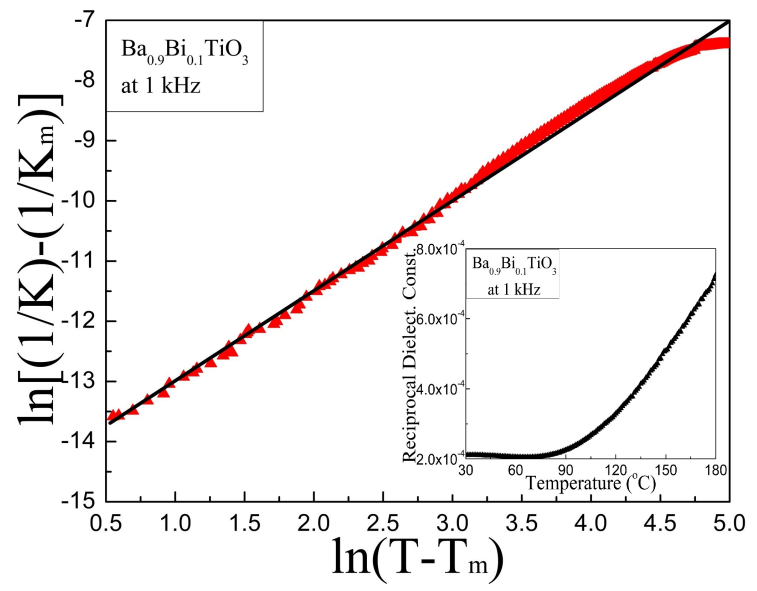

Figure 6. Plot of $\ln \left[(1 / K)-\left(1 / K_{m}\right)\right]$ vs. $\ln \left(T-T_{m}\right)$ for $\mathrm{Ba}_{0.9} \quad \mathrm{Bi}_{0.1} \mathrm{TiO}_{3}$ solid solution The inset shows the reciprocal of the dielectric constant of $\mathrm{Ba}_{0.9} \mathrm{Bi}_{0.1} \mathrm{TiO}_{3}$ vs. temperature.

tion of 0.1 mole $\%$ had a relatively stable effect on intrinsic dielectric phenomena, such as the Curie temperature and phase transition, because only partial nonuniformity existed. This variation in basic dielectric properties has been actively studied by numerous researchers on the basis of the physical change in $\mathrm{Ba}_{0.9} \mathrm{Bi}_{0.1} \mathrm{TiO}_{3}$ created by substituting/doping the $\mathrm{A}$ and $\mathrm{B}$ sites of $\mathrm{BaTiO}_{3}$. The atypical phase transition and dielectric characteristics of $\mathrm{Ba}_{0.9} \mathrm{Bi}_{0.1} \mathrm{TiO}_{3}$ obtained this study were similar to the phase transition and dielectric characteristics of $\mathrm{Ba}_{0.9} \mathrm{Sb}_{0.1} \mathrm{TiO}_{3}$ reported in previous studies [4]. Therefore, the phase transition temperature of $\mathrm{BaTiO}_{3}$ can be decreased and diffusivity can be increased while widening the phase transition temperature range.

\section{Conclusions}

A $\mathrm{Ba}_{0.9} \mathrm{Bi}_{0.1} \mathrm{TiO}_{3}$ solid solution was prepared by substituting 0.1 mole $\% \mathrm{Bi}_{2} \mathrm{O}_{3}$ at the $\mathrm{Ba}^{2+}$ sites in $\mathrm{BaTiO}_{3}$, and its dielectric properties were investigated. The solid solution was stably prepared by sintering at $1310{ }^{\circ} \mathrm{C}$ for $5 \mathrm{~h}$. XRD analysis showed that unlike pure $\mathrm{BaTiO}_{3}$, pyrochlore $\mathrm{Bi}_{2} \mathrm{Ti}_{2} \mathrm{O}_{7}$ was observed in $\mathrm{Ba}_{0.9} \mathrm{Bi}_{0.1} \mathrm{TiO}_{3}$ at approximately $27.1^{\circ}$. The perovskite structure was well formed. The dielectric properties were analyzed using the modified Curie-Weiss law. The dielectric properties of $\mathrm{Ba}_{0.9} \mathrm{Bi}_{0.1} \mathrm{TiO}_{3}$ were slightly different from those of $\mathrm{BaTiO}_{3}$. The plot of the dielectric constant vs. temperature showed stable changes over a wide temperature range, unlike the phase transition behavior of pure $\mathrm{BaTiO}_{3}$. As the measurement frequency increased, the dielectric constant of $\mathrm{Ba}_{0.9} \mathrm{Bi}_{0.1} \mathrm{TiO}_{3}$ decreased and its dielectric loss increased. At frequencies higher than $10^{3} \mathrm{~Hz}$, this increase and decrease were faster than those for $\mathrm{BaTiO}_{3}$. However, $\mathrm{Ba}_{0.9} \mathrm{Bi}_{0.1} \mathrm{TiO}_{3}$ showed stable dielectric properties over a wide temperature range. In the future, the close physical relationship between pyrochlore $\mathrm{Bi}_{2} \mathrm{Ti}_{2} \mathrm{O}_{7}$ and the dielectric properties, which was observed after $\mathrm{Bi}^{3+}$ substitution in $\mathrm{BaTiO}_{3}$, should be analyzed.

\section{References}

[1] H. F. Kay and P. Vousden, Philos. Mag. 40, 1019 (1949).

[2] A. J. Moulson and J. M. Herbert, Electroceramics: Materials, Properties, Applications (Wiley Press, New York, 2003).

[3] S. Liu, L. Zhang, J. Wang, X. Shi, Y. Zhao, and D. Zhang, Sci. Rep. 6, 38354 (2016).

[4] Y. J. Kim, Appl. Sci. Converg. Technol. 28, 126 (2019).

[5] D. Lin, S. T. Dong, Y. Y. Zhang, Y. Y. Lv, J. Zhou, Y. B. Chen, R. A. Mole, S. H. Yao, and D. Yu, J. Alloys Compd. 826, 154161 (2020). 
[6] S. Tangjuank and T. Tunkasiri, Appl. Phys. Lett. 90, 072908 (2007).

[7] R. Mahbub, T. Fakhrul, and Md. F. Islam, Procedia Eng. 56, 760 (2013).

[8] H. Z. Akbas, Z. Aydin, O. Yilmaz, and S. Turgut, Ultrason. Sonochem. 34, 873 (2017).

[9] A. Jain, N. Maikhuri, R. Saroha, M. Pastor, A. K. Jha, and A. K. Panwar, Adv. Mater. Lett. 7, 567 (2016).
[10] V. Paunović, V. Mitić, M. Marjanović, and L. Kocić, Electron. Energ. 29, 285 (2016).

[11] L. Zhou, P. M. Vilarinho, and J. L. Baptista, J. Am. Ceram. Soc. 82, 1064 (1999).

[12] S. Wu, X. Wei, X. Wang, H. Yang, and S. Gao, J. Mater. Sci. Technol. 26, 472 (2010)

[13] M. S. Alkathy, R. Gayam, and K. C. J. Raju, Ceram. Int. 42, 15432 (2016). 